Original Research Article

\title{
Hepatoprotective activity of ethanol extract of Pavetta Indica Linn leaves
}

\author{
Varkung Valte, M. Premchand Singh*, Indira Raleng, Losica R. K.
}

Department of Pharmacology, Jawaharlal Nehru Institute of Medical Sciences, Porompat, Imphal, Manipur, India

Received: 19 February 2018 Accepted: 28 March 2018

*Correspondence to:

Dr. M. Premchand Singh, Email: drpremcs@gmail.com

Copyright: (C) the author(s), publisher and licensee Medip Academy. This is an openaccess article distributed under the terms of the Creative Commons Attribution NonCommercial License, which permits unrestricted noncommercial use, distribution, and reproduction in any medium, provided the original work is properly cited.

\begin{abstract}
Background: Traditionally, the bark of Pavetta Indica Linn., in decoction or pulverized, is administered, especially to children, to correct visceral obstructions. The decocted leaves are used externally to alleviate the pains caused by hemorrhoids. The root, pulverized and mixed with the ginger and rice-water, is given in dropsy. A local fomentation with the leaves is useful in relieving the pain of piles. Paracetamol (PCM) toxicity generates free radicals and raised serum enzyme levels-SGPT, SGOT, Alkaline Phosphatase and S. Albumin. It causes necrosis, congested vessels, multifocal area of fatty changes nuclear disintegration, sinusoidal dilation, kuffer cell hyperplasia. The reverse is considered as the index of hepatoprotective activity. The present study is being taken up to screen hepatoprotective action of $P$. Indica Linn.

Methods: The acute liver damage in albino rats was induced by per oral administration of a single dose of $2000 \mathrm{mg} / \mathrm{kg}$ b.w. PCM suspension in $0.5 \%$ Carboxy methyl cellulose (CMC) and chronic liver damage by giving the same dose of PCM on the 7th day. The hepatoprotective activity was monitored biochemically by estimating S. transaminase, S. bilirubin and S. Protein on the 8th day of experiment.

Results: Ethanol extract of $P$. Indica inhibited PCM induced liver toxicity in albino rats at $100 \mathrm{mg} / \mathrm{kg}$ and $200 \mathrm{mg} / \mathrm{kg}$ b.w as assessed by the biochemical values. Conclusions: Ethanol extract of " $P$. Indica" exhibited significant hepatoprotective activity.
\end{abstract}

Keywords: Carboxy methyl cellulose, Ethanol, Flavonoids, Hepatoprotective activity, Pavetta Indica Linn, Paracetamol, Silymarin

\section{INTRODUCTION}

Since time immemorial, people have been using plants and herbs as medicines for the treatment of many kinds of diseases. The Rig Veda, dating 3500 B.C to 1800 B.C seems to be the earliest record available on medicinal plants. The world health organization (WHO) estimated that $80 \%$ of the population of the developing countries relies on traditional medicines, mostly of plants origin and local health practitioner for their primary health care needs. ${ }^{1}$ Plants continue to serve as possible sources of new drugs and chemicals derived from various parts of plants. ${ }^{2}$
Plant derived natural products such as flavonoids, terpenoids, saponins and sterols have received considerable attention in recent years due to their diverse pharmacological properties including antioxidant and hepatoprotective activity. Due to the absence of reliable drugs for the management of liver ailments in the modern medicine, plants and natural products are providing to be hepatoprotectants as evident from voluminous published work on their hepatoprotective potentials.

The scientific study of the plants for various medicinal properties should be an important aspect for the scientific validation of folklore claims of the inhabitants with regard 
to the utility of the plants as well as this can be a new source of herbal drugs. ${ }^{3}$ A variety of plants have been studied which support liver functions and are used to treat diseases of the liver, but still there is a need toexplore more hepatoprotective plants. Keeping this in view, the present study has been undertaken to investigate hepatoprotective activity of ethanol extract of Pavetta indica Linn. on paracetamol induced liver damage in rats.

Objective of the study was to investigate the hepatoprotective activity of ethanol extract of Pavetta Indica Linn leaves.

\section{METHODS}

\section{Plant material and extract}

$P$. Indica leaves were collected randomly from Imphal east district of Manipur State, and authentication of the plant was done by Department of life sciences, Manipur University, Canchipur, Imphal, Manipur state.

Kiritkar KR et al, and Thabrew MI et al, reported that the plant leaves were used in the treatment of liver diseases, pain of piles, urinary diseases and fever. ${ }^{4,5}$ Ethanol extract of $P$. Indica leaves was obtained by the extraction procedure as described by Chattopadhyay with slight modification. ${ }^{6}$ Powder leaves was defatted with petroleum ether (60-80 c) and Soxhlet extraction with $99.9 \%$ ethanol. Further the ethanol extract was distilled and solvent ethanol removed. The residue extract was dried and measured. The yield was $28 \mathrm{gm}$. The extract thus obtained was used as the study material in the entire study for its hepatoprotective activity in albino rats. Various phytochemical constituents like flavonoids and their glycosides, alkaloids, sterols, phenolics, lignins, terpenoids, coumarins, fatty acids, saponins have been isolated from this plant. ${ }^{7}$

Recent time, focus in plant research has increased all over the world and a large body of evidence has collected to show immense potential of medicinal plants used in various traditional system. ${ }^{8}$

\section{Toxicity testing}

Acute oral toxicity study for the test extract of $P$. Indica was carried out using OECD/OCED Guideline 425. ${ }^{9}$ The test procedure minimizes the no. of animals required to estimate the oral acute toxicity. Healthy, young adult albino rats $(100-200 \mathrm{~g})$ were used for this study. $1 / 10^{\text {th }}$ $1 / 20^{\text {th }}$ of acute toxicity dose $(2000 \mathrm{mg})$ was taken as daily dose in the experimental models.

\section{Hepatoprotective studies}

For the study of hepatoprotective activity of ethanol extract of $P$. Indica leaves, the method of Rajasekaran A et al, was followed with slight modification. ${ }^{10}$
Singh BN and Saravanan N evaluated the aqueous extract of $P$. Indica leaves against carbon tetrachloride induced hepatotoxicity in rats. ${ }^{11}$ It showed a decreased in the serum enzymatic level of ALT, AST, ALP, total bilirubin. The effects produced were comparable to that of a standard hepatoprotective agent. The results indicated that the $P$. Indica leaves possessed significant hepatoprotective activity.

Muthu AK et al, clearly indicated the methanolic extract of $P$. Indica showed strong antioxidant activity by inhibiting super oxide anion scavenging activity, nitric oxide radical scavenging activities when compared with standard quercetin and ascorbate. ${ }^{12}$

As experimental animals, rats have been employed extensively because of the size and low cost and being omnivorous, rats resemble man nutritionally. Paracetamol can be administered intragastrical or intraperitoneally. ${ }^{13,14}$

Antihepatotoxic potential of Silymarin against several chemicals were reported by various workers. ${ }^{15}$

Paracetamol overdose may cause severe hepatotoxicity and sometimes even fatal liver failure and centrilobular hepatic necrosis in humans and experimental animals. ${ }^{16}$

\section{Test drug}

The ethanol extract of $P$. Indica leaves was suspended in $0.5 \%$ Carboxy methyl cellulose sodium (CMC) and given orally at a dose of 100 and $200 \mathrm{mg} / \mathrm{kg}$ respectively for 7 days.

\section{Animal}

Albino rats of either sex-100-200g. Animals were acclimatized for 10days, feed with standard pellet diet and water ad libitum.

\section{Induction of hepatic injury}

The acute liver damage in albino rats was induced byper oral administration of a single dose of $2000 \mathrm{mg} / \mathrm{kg} \mathrm{b}$.w. PCMsuspension in $0.5 \%$ Carboxy methyl cellulose (CMC) and the chronic liver damage by giving the same dose of PCM on the $7^{\text {th }}$ day.

Treatment of animals: 35 healthy albino rats were divided into 5 groups of 6 each for hepatoprotective testing.

1. Group 1 (normal control) served as a control and received normal saline, $5 \mathrm{ml} / \mathrm{kg}$ body weight, daily for 7 days.

2. Group 2 (toxic control) constituted the hepatotoxic group and was treated similarly to group 1 .

3. Group 3 (Test dose 1) received ethanol extract of $P$. Indica $100 \mathrm{mg} / \mathrm{kg}$ body weight per day suspended in $0.5 \%$ CMC for 7 days. 
4. Group 4 (Test dose 2) received ethanol extract of $P$. Indica $200 \mathrm{mg} / \mathrm{kg}$ body weight per day suspended in $0.5 \%$ CMC for 7 days.

5. Group 5 (standard) were given the standard drug, Silymarin $100 \mathrm{mg} / \mathrm{kg}$ body weight daily) for 7 days.

6. On the $7^{\text {th }}$ day, paracetamol suspension in $0.5 \% \mathrm{CMC}$ was given orally, $2 \mathrm{~g} / \mathrm{kg}$ body weight, to all the Groups except Group 1, which was given CMC.

\section{Preparation of samples for biochemical studies}

After induction of hepatotoxicity, on the $8^{\text {th }}$ day of the experiment the blood was withdrawn from orbital sinus by using capillary tube as mention by Rao KS and Mishra SHfor analysis of liver parameters. ${ }^{17}$

All rats were anaesthetized with ether and blood was withdrawn from orbital sinus by using capillary tube.The most efficient method of collecting blood in rats and mice causing least stress to the animals is from the orbital sinus with the help of a capillary tube. ${ }^{18}$ Then the blood was kept for 30 minutes without disturbing. The clots were dispersed with glass rod and then centrifuged for 20 minutes at $2000 \mathrm{rpm}$ to separate the serum. The serum of each animal of all groups was estimated for SGPT, SGOT, bilirubin and total protein content.

Lablife chem Master instrument was used for the estimation of different biochemical parameters included in the present study. It is a semi automated chemistry analyser made by DIAGNOVA. SGPT and SGOT were determined by Reitman and Frankel method (using kits from span Diagnostic Ltd.). ${ }^{19}$ Malloy and Evelyn method was followed to estimate total bilirubin content and Biuret (manual) method for the measurement of total protein. ${ }^{20,21}$

Table 1: Effect of ethanol extract of $P$. Indica on serum level of SGPT, SGOT, direct bilirubin, total bilirubin, albumin, globulin and total protein in paracetamol induced hepatotoxicity in albino rats.

\begin{tabular}{|c|c|c|c|c|c|c|c|}
\hline Treatment & SGOT & SGPT & $\begin{array}{l}\text { Direct } \\
\text { bilirubin }\end{array}$ & $\begin{array}{l}\text { Total } \\
\text { bilirubin }\end{array}$ & Albumin & Globulin & $\begin{array}{l}\text { Total } \\
\text { protein }\end{array}$ \\
\hline $\begin{array}{l}\text { Group } 1 \\
\text { CMC }\end{array}$ & $71 \pm 2.36$ & $102.67 \pm 6.74^{c}$ & $0.53 \pm 0.25$ & $0.92 \pm 0.5$ & $3.25 \pm 0.4$ & $2.317 \pm 0.42^{b}$ & $5.53 \pm 0.3$ \\
\hline $\begin{array}{l}\text { Group } 2 \\
\text { Toxic control (PCM) }\end{array}$ & $135.17 \pm 4.99^{b}$ & $147.5 \pm 5.68^{b}$ & $0.98 \pm 0.34$ & $2.78 \pm 0.6^{\mathrm{a}}$ & $1.12 \pm 0.38^{b}$ & $1.5 \pm 0.18^{\mathrm{a}}$ & $2.62 \pm 0.36^{\mathrm{b}}$ \\
\hline $\begin{array}{l}\text { Group } 3 \\
\text { P. indica }(100 \mathrm{mg} / \mathrm{kg}) \\
+ \text { PCM }\end{array}$ & $101.5 \pm 4.7^{\mathrm{a}}$ & $123.17 \pm 9.1^{\mathrm{a}}$ & $0.92 \pm 0.41$ & $1.57 \pm 0.49$ & $2.52 \pm 0.5^{\mathrm{c}}$ & $1.78 \pm 0.38^{\mathrm{ab}}$ & $4.35 \pm 0.37^{\mathrm{a}}$ \\
\hline $\begin{array}{l}\text { Group } 4 \\
\text { P. indica }(200 \mathrm{mg} / \mathrm{kg}) \\
+ \text { PCM }\end{array}$ & $100.5 \pm 6.53^{\mathrm{a}}$ & $108.33 \pm 7.84^{c}$ & $0.6 \pm 0.1$ & $1.17 \pm 0.28$ & $2.4 \pm 0.41^{\mathrm{ac}}$ & $2.37 \pm 0.32^{b}$ & $4.6 \pm 0.46^{\mathrm{a}}$ \\
\hline $\begin{array}{l}\text { Group } 5 \\
\text { Silymarin } \\
(100 \mathrm{mg} / \mathrm{kg})+\mathrm{PCM}\end{array}$ & $74.17 \pm 20.83$ & $102.5 \pm 5.5$ & $0.97 \pm 0.28$ & $1.26 \pm 0.31$ & $3.12 \pm 0.2$ & $2.62 \pm 0.55$ & $5.73 \pm 0.6$ \\
\hline
\end{tabular}

Mean $\pm S D(n=6)$. Within a column means marked with different superscript letters are significantly different $(\mathrm{p}<0.001-0.05)$ as analyzed by Tukey-Kramer multiple comparisons test.

\section{RESULTS}

The ethanol extract of $P$. Indica was found to be safe and there was no mortality up to $2000 \mathrm{mg} / \mathrm{kg}$ body weight p.o. after 14 days. $1 / 10^{\text {th }}-1 / 20^{\text {th }}$ of this dose was selected to carry out the hepatoprotective activity studies. Serum enzymes level was very high in rats challenged with PCM. In group 3 and 4, the enzymes activity is significantly lowered when compared to that of group 2 and the values are closer to that of normal control. There is no significant raise in total bilirubin in groups treated with the test extract dose 1 and 2. Also the total protein values are near normal in those rats in which test extract was given. The total bilirubin for normal control group was $1.25 \pm 0.31$ and total protein level for normal control group was $5.73 \pm 0.65$ which were in conformity with the finding of Oinam et al. $^{22}$

\section{DISCUSSION}

The present study shows that ethanol extract of $P$. Indica has remarkably good hepatoprotective effect in acute and chronic studies. The elevation in the plasma levels in group 2 reflects that the liver injury is induced by PCM.In the present study, normal control group (mean \pm SEM U/L) level of AST and ALT were 74.17 \pm 20.84 and 102.50 \pm 5.51 respectively which were in conformity with the findings of Palanivel $\mathrm{M}$ et al, and Anbarasu et al, and the total bilirubin for normal control group was $1.25 \pm 0.31$ and total protein level for normal control group was $5.73 \pm 0.65$ which were in conformity with the finding of Anbarasu et al..$^{23,24}$ 
There was significant $(\mathrm{P}<0.001)$ rise in AST

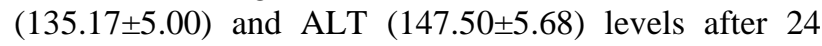
hours of Paracetamol administration in toxic control group when compared to normal control (71.00 \pm 2.37 ; $102.67 \pm 6.74)$ group which was in conformity with the finding of Rao KS and Mishra SH. ${ }^{25}$ The serum total bilirubin level in toxic control $(2.78 \pm 0.60)$ is significantly high $(\mathrm{P}<0.001)$ when compared to normal control group $(0.92 \pm 0.51)$ which was in conformity with the finding of Shenoy KA et al. ${ }^{26}$ The serum total protein level in toxic control group $(2.62 \pm 0.37)$ was significantly reduced $(\mathrm{P}<0.001)$ when compared to normal control group $(5.53 \pm 0.31)$ which was in conformity with the finding of Venukumar and Latha MS. ${ }^{27}$

The extract decreased the PCM induced elevated enzymes levels in Group 3 and 4are suggestive of production of the structural integrity of hepatocytes cell membrane or regeneration of damaged liver cells by the extract. Lower serum bilirubin level and near normal protein levelin extract treated groups 3 and 4 indicate the effectiveness of the extract in normal functional status of the liver.

The results of the present investigation infer that ethanol extract of Pavetta Indica Linn leaves possess fairly good hepatoprotective activity.

Funding: No funding sources

Conflict of interest: None declared

Ethical approval: The study was approved by the Institutional Ethics Committee

\section{REFERENCES}

1. Vijayan K, Vetriselvi J, Balu S. Plant medicines for human ear disease. J Econ Tax Bot. 2003;27:851-56.

2. Tijani AY, Uguru MO, Salawu OA. Antipyretic, antiinflammatory and anti-diarrhoeal properties of FaidherbiaAlbida in rats. Afr $\mathrm{J}$ Biotectol. 2008;7(6):696-700.

3. Pushpangandan P. Role of traditional medicine in primary health care. In: Iyengar PK, Damodaran VK, Pushpangadan P, Editors. Science for health Kerala: Staff committee on science, technology and environment, Govt. of Kerala; 1995.

4. Kritikar KR, Basu BD. Indian medicinal plants. Allahabad, India: Bio-green books; 1933:1786-1789.

5. Thabrew MI, Joice PD, Rajatissa W. A comparative study of the efficacy of Pavetta indica Linn. and Osbeckia octanda in the treatment of liver dysfunction. Planta Med. 1987;53:239-41.

6. Chattopadhyay RR. Possible mechanism of hepatoprotective activity of Azadirachta indica leaf extract: part-11. J Ethano pharmacol. 2003;89:217-19.

7. Kokate C.K. Practical pharmacognosy. $4^{\text {th }}$ Ed. Pune: Vallabh Prakashan; 1996:107.

8. Dhanukar SA, Kulkarni RA, Rege NN. Pharmacology of medicinal plants and natural products. Indian J Pharmacol. 2000;32:81-119.
9. OECD guidelines for the testing of chemicals (Acute oral toxicity-up and down procedure). [Cited 2008 March 20]. Available at: http://www.oecd.org [Last accessed on 2006 March 23].

10. Rajasekaran A, Periyasamy M. Hepatoprotective effect of ethanolic extract of Trichosanthes lobata on paracetamol induced liver toxicity in rats. Chinese medicine. 2012;7:12.

11. Singh BN, Saravanan N. The effect of Pavetta indica Linn. in PCM induced hepatotoxicity in rats. Pharm Glob Int J Compr Pharm. 2012;3(6):1-4.

12. Thayyil AH, Muthu AK, Mohammed. Free radical scavenging activity of various extracts of whole plant of Pavetta indica (Linn): An in-vitro evaluation. Int $\mathbf{J}$ Pharm Drug Anal. 2016;4(2):44-8.

13. Zimmerman HJ. Experimental hepatopathology, experimental hepatoxicity. New York: Appleton; 1978:167-197.

14. Dutta S, Basu K, Sinha S, Bhattacharyya P. Hepatoprotective effect of a protein isolated from Cajanus indica (spreng) on carbon tetrachloride induced hepatotoxicity in mice. Indian J Expt Biol. 1998:175-81.

15. Rajnarayana K, Reddy MS, Chaluvadi MR, Krishna DR. Bioflavonoids classification, pharmacological, biochemical effects and therapeutic potential. Indian J Pharmacol. 2001;33:2-16.

16. Ghadlinge MS, Jaju JB, Chandane RD, Jadhav RR, Bhosle RR. A study of effect of Nigella sativa oil in paracetamol induced hepatotoxicity in albino rats. International Journal of Basic \& Clinical Pharmacology. 2017 Jan 24;3(3):539-46.

17. Rao KS, Mishra SH. Anti-inflammatory and hepatoprotective activities of fruits of Moringa pterygo spermagaertn. Ind J Nat Prod. 1998;14:3.

18. Gosh MN. Fundamentals of experimental Pharmacology. In: Common laboratory animals. Kolkata: Hilton and Company; 2015:14

19. Reitman S, Frankel SA. Colourimetric method for the determination of serum oxaloacetatic and glutamic pyruvic transaminases. American Journal Clinical Pathology. 1957;28:56-63.

20. Malloy HT, Evelyn KA. The determination of bilirubin with the photometric colorimeter. J Biol Chem. 1937;119:481-90.

21. Gornall AG, Bardwill CJ, David MM. Determination of serum proteins by means of the biuret reaction. $\mathrm{J}$ Biol Chem. 1949;177:751-6.

22. Oinam J, Raleng I, Meitankeishangbam P, Rajkumari B, Laishram S. A study on hepatoprotective study on Zanthoxylum armtum DC (Mukthrubi) leaves in experimental animal. IJSPR. 2017;8(7):3025-29.

23. Palanivel MG, Rajkapoor B, Kumar RS, Einstein JW, Kumar EP, Kumar MR, et al. Hepatoprotective and antioxidant effect of Pisonia aculeate L. against $\mathrm{CCl} 4$ - induced Hepatic Damage in rats. Sci Pharma. 2008;76:203.

24. Anbarasu C, Rajkapoor B, Kalpana J. Protective effect of Pisonia aculeata on paracetamol induced 
hepatotoxicity in rats. J Exp Integr Med. 2011;1:16772.

25. Rao KS, Mishra SH. Anti-inflammatory and hepatoprotective activity of Sida Rhombifolia Linn. Indian J Pharmacol. 1997;29:110-6.

26. Shenoy KA, Somayagi SN, Bairy KL. Evaluation of Hepatoprotective activity of Ginko Biloba in rats. Indian J Pharmacol. 2002;46(2):167-74.

27. Venukumar MR, Latha MS. Hepatoprotective effect of the methanolic extract of Curculigo orchioides in carbon tetra chloride treated male rats. Indian $\mathbf{J}$ Pharmacol. 2002;34:269-75.

Cite this article as: Valte V, Singh MP, Raleng I, Losica RK. Hepatoprotective activity of ethanol extract of Pavetta Indica Linn leaves. Int J Basic Clin Pharmacol 2018;7:1006-10. 